\title{
Going against the flow: Effects of river damming in Cuban fisheries
}

\author{
Julio A. Baisre*, Zenaida Arboleya \\ Ministerio de la Industria Pesquera, Barlovento, Santa Fe 19 100, Playa, La Habana, Cuba
}

Received 8 December 2005; received in revised form 10 April 2006; accepted 25 April 2006

\begin{abstract}
Over the last decade eutrophication of freshwater artificial reservoirs in Cuba occurred in parallel to oligotrophication of estuarine and coastal waters. These two processes influenced both freshwater and marine fisheries. A dramatic shift in species composition in freshwater fisheries has occurred, from dominance by cichlids (tilapia) to dominance by cyprinids. The high fishery yield from some reservoirs, and shift in species composition, seems related to progressive eutrophication of reservoirs by nutrient subsidies from different anthropogenic activities; particular those related to the size of urban areas within their watersheds.

On the other hand, marine landings of estuarine-dependent species declined more significantly than for other groups associated with seagrass beds-coral reefs and oceanic waters. The ratio between catches of estuarine-dependent species and those associated with seagrass beds and coral reefs, decreased significantly over the last 20 years. The decrease in landings was more evident in typical estuarine species, such as shrimps (Litopenaeus schmitti and Farfantopenaeus notialis), mangrove oyster (Crassostrea rhizophorae) and mullets (Mugil spp.). River damming increased during the same period and is significantly correlated with these decreases.

It is hypothesized that two different processes acted synergistically, leading to dramatic decreases of several orders of magnitude, in the catches of estuarine species over the last decade: the trapping of nutrients and sediments by river damming, and a drastic reduction in nutrient inputs from land-based sources due to reduced fertilizer use. These are postulated to have affected not only estuarine resources, but also the whole coastal ecosystem.
\end{abstract}

(C) 2006 Elsevier B.V. All rights reserved.

Keywords: Marine fisheries; Reservoir fisheries; Eutrophication; Oligotrophication; River damming; Anthropogenic impacts

\section{Introduction}

Three main categories of nutrient enrichment processes occur in the coastal zone: (1) coastal upwelling, (2) tidal mixing and (3) land-based runoff and river outflow (Caddy and Bakun, 1994). Since Cuba is located in the oligotrophic Caribbean Sea, in the absence of significant coastal upwelling and with a very small tidal range, river discharge of terrestrial material in particulate and dissolved form is the most important source of nutrients supporting marine coastal fisheries (Baisre, 1985).

In some ecosystems it is known, that moderate enrichment from land-based sources occasionally leads to increased populations of economically valuable fishes (Howarth et al., 2000), and continuous growth of human population can lead to an increase of nutrients inputs to coastal waters. However, a reduction in nutrient outflows into coastal areas might also occur due to

\footnotetext{
* Corresponding author. Tel.: +53 7209 7253; fax: +53 72097253 .

E-mail address: baisre@ @elemar.cu (J.A. Baisre).
}

human interruptions to the natural flow patterns of rivers, or more exceptionally, and this is a main focus of the paper, in the case of Cuba, where the use of fertilizers for agricultural purposes has been drastically reduced (Baisre, in press).

The impoundment of freshwater in rivers has been used for power generation, and flows diverted for irrigation purposes and to reduce threats by flooding during extreme rainfall events (Arthurton, 2005). Because rivers are still the major channels for water, nutrients and organic and particulate matter passing from land to sea, the construction of dams had an immediate and profound impact on river inputs to the ocean (Chen, 2002). The impact of reservoir development might be expected to lead to a decrease in nutrients exports from catchments (Vörosmarty et al., 1997). Reservoirs increase water residence times, thus allowing greater biotic uptake by freshwater vegetation, but in excess, may lead to anoxic bottom water conditions that promote denitrification, and further reduce exports of $\mathrm{N}$ to downstream waters (Downing et al., 1999). By the early 1990s, more than $13 \%$ of the global river flow to the sea had already been dammed or diverted (Chen, 2002). The interruption of natural fluxes 


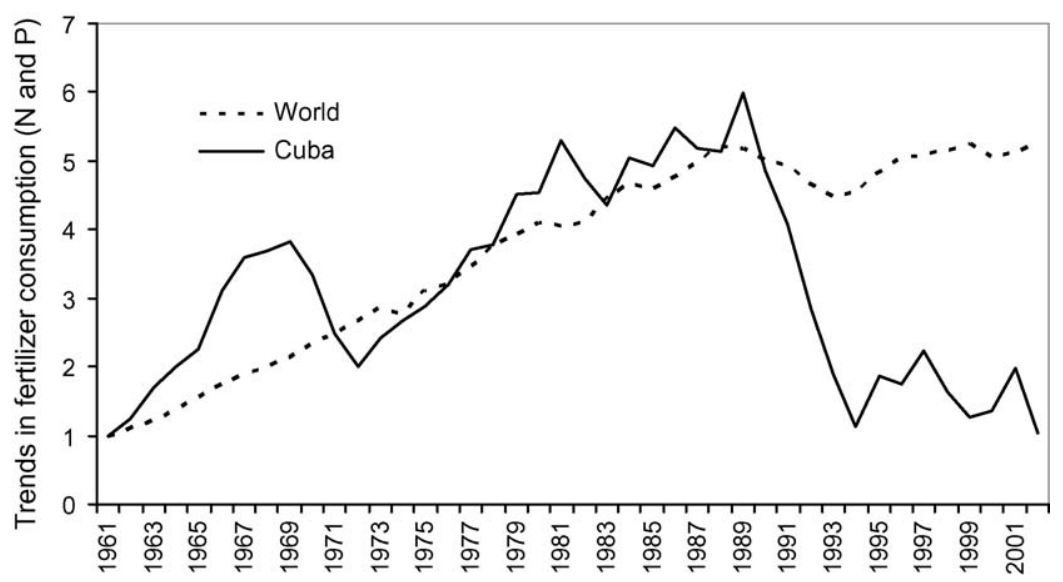

Fig. 1. Trends of fertilizer consumption (1961-2002). The first year of the series (1961) represent the baseline (1). Fertilizer consumption in Cuba is well above the world trend until 1989.

of water, nutrients and sediments by river regulation can be expected to have had significant ecological impacts downstream from dams.

There was evidence of a drastic reduction in $\mathrm{N}$ inputs to the Cuban landscape during the1990s due to a serious contraction in the rural economy, in particular, a dramatic reduction in fertilizer use (Fig. 1) and the burning of fossil fuels (Baisre, in press). We present evidence here that nutrient retention in reservoirs and other ecological changes derived from river damming had severe impacts on the ecology of estuarine areas and on coastal fisheries. An analysis of how nutrient retention has impacted fisheries in artificial reservoirs is also presented.

\section{Materials and methods}

Data on annual catches of both freshwater and marine species used in this paper come from the Planning and Statistical Division at the Ministry of Fisheries. Yearly catch data for all the species can be accessed through FAO fisheries statistical database (FAOSTAT, 2005). The data on fish yield of the different reservoirs as well as the number of fingerlings that have been stocked were provided by the Department of Aquaculture. Data on population density of the urban centres in the neighborhood of the reservoirs were obtained from the National Yearbook of Statistics (ONE, 2005). The information on river damming, general hydrology as well as the data on the Cauto River watershed were all obtained from the National Institute for Hydrology (INRH, 2005) and can be accessed through the Cuban database on water resources. The annual average outflow of the Cauto River was calculated using the modified Schreiber empirical formula which is valid for tropical and temperate regions (database from LOICZ, 2005), and is based on monthly rainfall and temperature data averaged over a 50-year period. This figure was not very different from the estimated average annual flow of 1972 millions $\mathrm{m}^{3}$ obtained from INRH (2005). Data on nitrogenous and phosphate fertilizer consumption was obtained from FAOSTAT (2005), the FAO statistical database. The trends in the catches of the marine species were calculated from 1980 to 2003 . New dams have not been built since 1991.

\subsection{General hydrology}

In Cuba, many watersheds cross the axis of the main island and in consequence, most rivers are short with limited outflows. Much of the bedrock is of limestone and some rivers flow underground for part of their trajectory. Out of 633 rivers, almost $60 \%$ discharge onto the south coast, including the largest, the Cauto and the second largest, the Zaza, which drain into the Gulfs of Guacanayabo and Ana Maria, respectively. After Hurricane Flora passed over Cuban territory in 1963 leading to severe flooding, a national policy for water regulation was implemented. By 2004, 971 larger dams (more than 30 ha) and 730 small dams had been constructed (INRH, 2005). The average water volume in these artificial reservoirs represents $29.4 \%$ of the average annual flow of rivers generated by precipitation, estimated at 31, 6 millions of $\mathrm{m}^{-3}$ (FAO/AQUASTAT, 2000).

\subsection{Marine resources}

Baisre (1985) described three ecological complexes in Cuban marine waters in terms of the decreasing influence of land on marine fisheries. These are: the estuarine-littoral complex, the seagrass-coral reef complex, and that associated with oceanic waters (Fig. 2). The estuarine-littoral complex is particularly influenced by terrestrial fluxes and is typical of wetlands, estuaries and lagoons dominated by terrigenous material and mangroves. Ecologically, these habitats are subject to major envi-

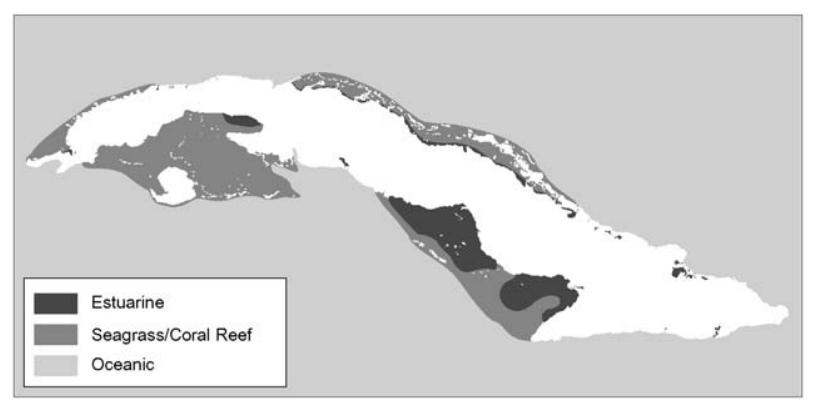

Fig. 2. Map of the marine area occupied by the three fisheries ecological complexes. 


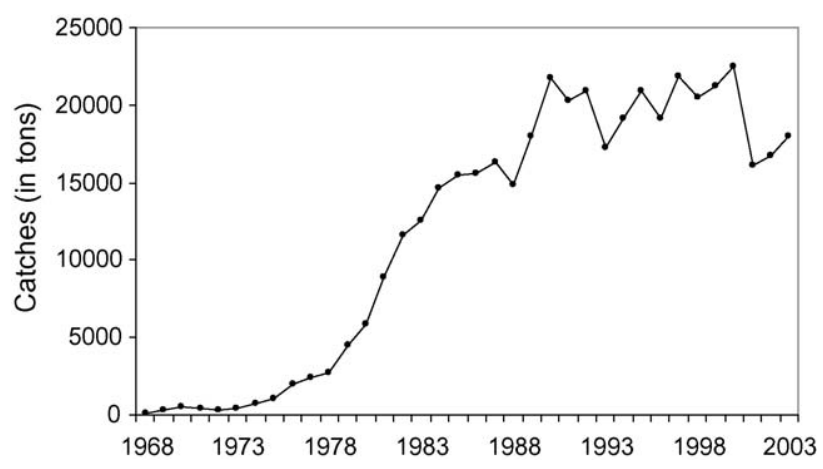

Fig. 3. Total landings of freshwater fishes (1960-2004) from reservoir fisheries in Cuba. Source: Department of Aquaculture. Ministry of Fisheries of Cuba.

ronmental changes, often accentuated by an unpredictable rainy season. They show elevated levels of primary production and organic detritus production which forms the basis for relatively simple coastal food webs. The estimated area of the estuarine-littoral complex is about $8500 \mathrm{~km}^{2}$; approximately $16 \%$ of the total shelf area, and reaches its greatest extent on the southeast coast in the Gulfs of Ana Maria and Guacanayabo into which the two largest river systems of the country drain.

The seagrass-coral reef ecological complex encompasses an approximate area of $45,000 \mathrm{~km}^{-2}$ and is the most important for Cuban fisheries. Extensive shallow waters areas with seagrass beds, patches of intermittent coralline outcrops, sponges and gorgonians on sandy or rocky bottom are a prominent feature of the Cuban shelf. Detailed information on the extension and distribution of the three fisheries ecological complex, the species composition and some other ecological data are given by Baisre (1985).

\section{Results}

\subsection{Changes in freshwater fish species composition}

A great number of Cuban reservoirs are used for extensive aquaculture which produces some 20,000 tonnes of fresh- water fishes annually in approximately 110,000 ha of surface area. The fishery yield over the last 5 years has averaged $130-150 \mathrm{~kg} \mathrm{ha}^{-1}$ year $^{-1}$. (Data from the Ministry of Fisheries.) Total freshwater fish landings in Cuba are shown in Fig. 3. All of this production is supported by periodical stocking of the reservoirs with fingerlings of tilapia (Oreochromis spp.), and different species of Chinese carp. The silver carp (Hypophthalmichthys molitrix) is, by far the most important species, although the bighead carp (Hypophthalmichthys nobilis) is also well represented in catches, and some other species such as the common carp (Cyprinus carpio) and grass carp (Ctenopharyngodon idella) make a small contribution to commercial catches. After a relatively long period of extensive aquaculture development, the species composition of landings has changed dramatically (Fig. 4) with a marked shift from dominance by tilapia to dominance by cyprinids.

If we consider that these differences are not related to fishing practices which have not changed very much, then they must be associated with other anthropogenic influences such as the preferential stocking with cyprinid fingerlings, or other ecological changes occurring within the reservoirs. While tilapias reproduce extensively and intensively under ecological conditions of Cuban reservoirs, other species of cyprinids, except the common carp, do not reproduce naturally in our reservoirs. Data on yearly stocking with tilapia and cyprinids are presented in Fig. 5, but cannot explain the dominance by cyprinids which began since 1995 when stocking of tilapia was higher than of cyprinids. The conclusion seems inevitable that other human activities within the watersheds, such as the progressive eutrophication of artificial reservoirs, are the main alternative hypothesis which accounts for this shift in species composition.

The water-based transport system for human and industrial waste has increased nutrient supply to the newly built reservoirs. This has led to a rapid eutrophication of reservoirs, which are primarily located in lowland regions. In Cuba, urban areas, as well as intensive livestock production and sugar mills, are major exporters of nitrogen $(\mathrm{N})$ and phosphorus $(\mathrm{P})$ to reservoirs located downstream. These special environments receive a high

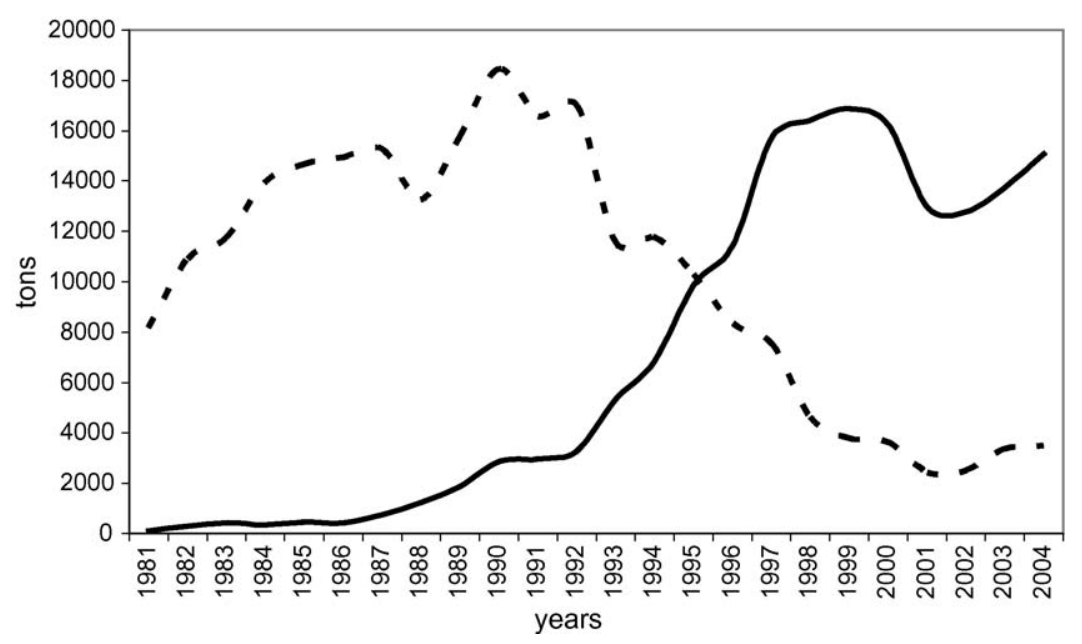

Fig. 4. Changes in species composition of catches from reservoir fisheries. Note the shift since 1996 from a tilapia-dominated system (broken line) to a cypriniddominated system (solid line). 


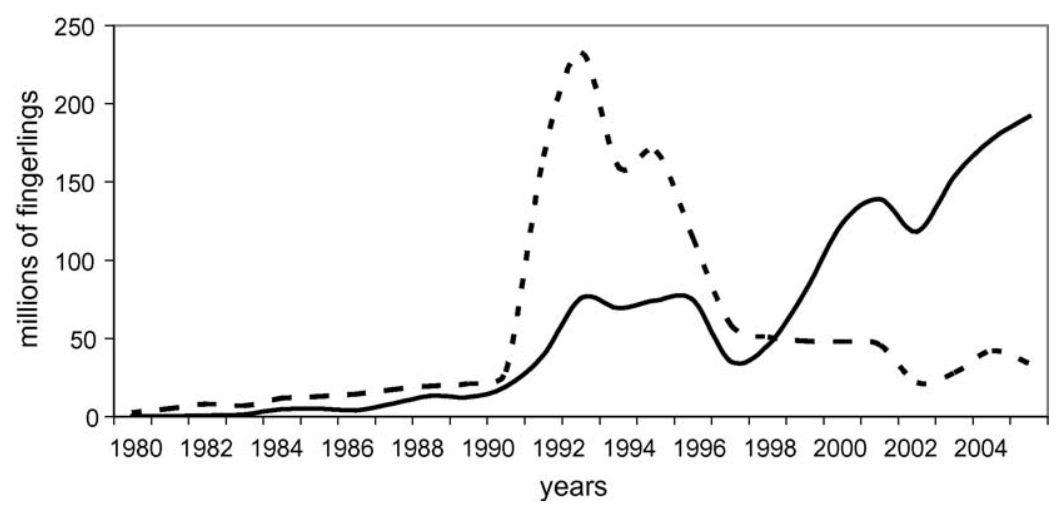

Fig. 5. Numbers of fingerlings of tilapia (broken line) and cyprinids (solid line) stocked every year.

input of material and influences from adjacent landmasses, but have a limited capacity to absorb impacts from human activities. Because dams are small patches within the terrestrial focal points of surrounding catchments, their productivity is highly dependent on regular subsidies from the surrounding landscape, and can be expected to be sensitive to human population density, agricultural practices, pollution and land use changes within the watershed. This is well illustrated by analyzing the yields of two of the more productive dams: Zaza and Jimaguayú, which are enriched by the sewage and industrial waste from the cities of Sancti Spiritus and Camagüey, respectively (Fig. 6).

In Fig. 7, we have plotted population density expressed as number of persons in urban areas, against the fisheries yield of a group of reservoirs that are commercially exploited and downstream from the urban areas in question. For this analysis fisheries yield was considered to be largely influenced by nutrient enrichment while the population density in upland areas was considered the driving force for nutrient inputs to the reservoirs. Allowing for possible variations between years due to differences in stocking densities of fish or changes in fishing effort,

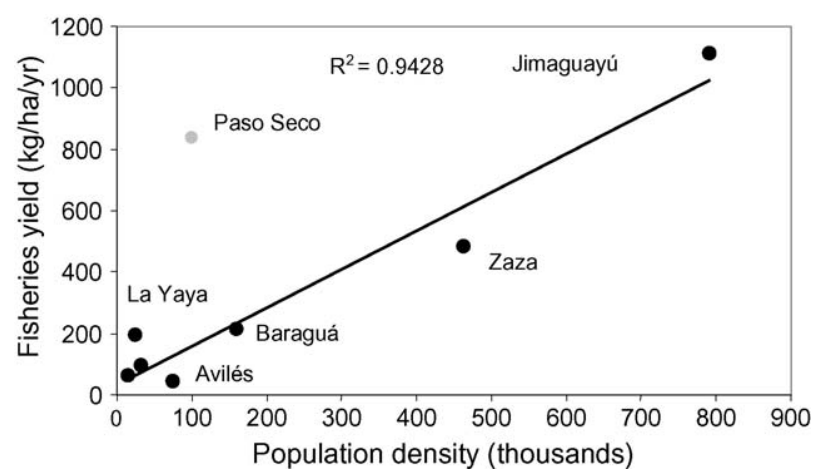

Fig. 7. Linear regression between fisheries yield (a 10-year average) and the upland urban population (number of persons) for eight different reservoirs. The grey point represents a reservoir with an intensive agricultural area within its watershed and was not included in the regression.

we used a 10-year average of fishery yield, and expressed it as $\mathrm{kg} \mathrm{ha}^{-1}$ year $^{-1}$. These reservoirs show a gradient from those that receive waters from relatively unpopulated mountain areas, to those which are close to relatively large centres of popula-

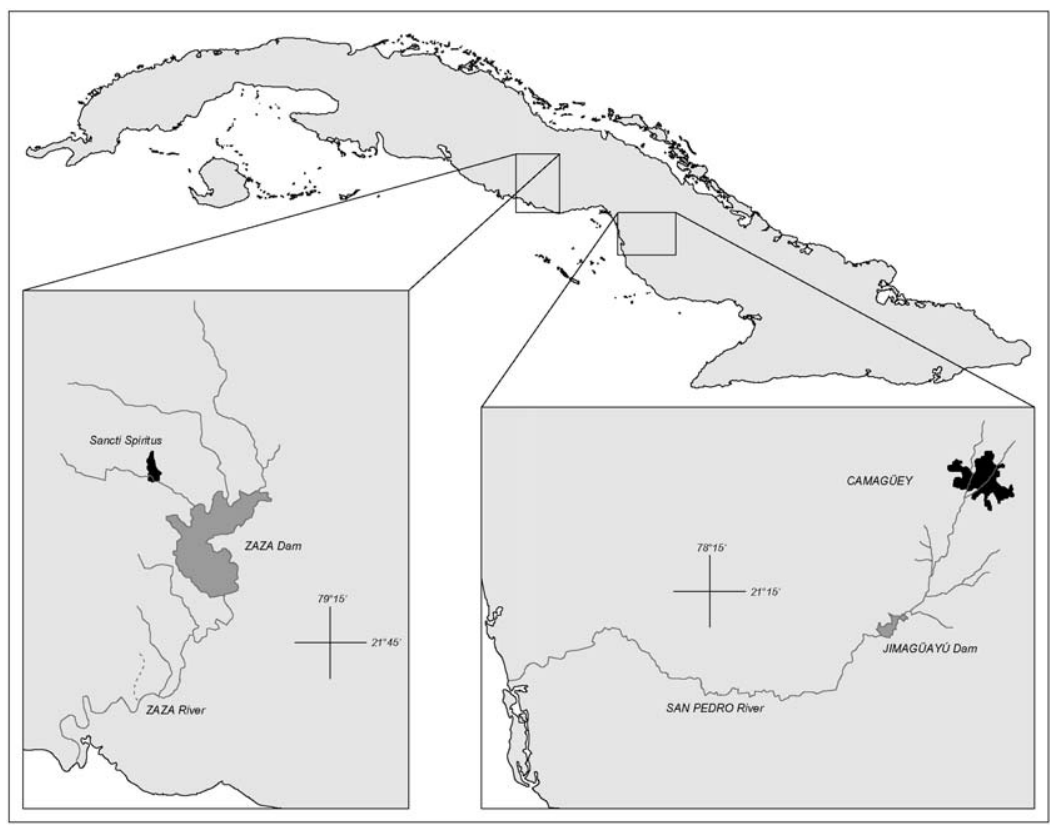

Fig. 6. Map of Cuba showing the location of the Zaza and Jimaguayú dams and reservoirs (inset); both enriched by sewage and industrial waste coming from the cities of Sancti Spíritus and Camagüey, respectively. 
tion. As a result of this analysis, a strong positive relationship was found $\left(R^{2}=0.9428, P<0.001\right)$ between population density and the average fisheries yield. Many human activities in the watershed (e.g., agriculture, human and industrial waste discharges) might promote eutrophication of the reservoirs of Zaza and Jimaguayú and are all related to population density. The intercept of the regression equation $\left(45 \mathrm{~kg} \mathrm{ha}^{-1} \mathrm{year}^{-1}\right)$, is a relatively good descriptor of the average fisheries yield that was previously obtained from Cuban reservoirs prior to the onset of strong anthropogenic influences from upstream. Fishery yield from the Paso Seco reservoir represents an outlier, and this data point was not included in the regression equation. The high yield shown by this reservoir is not correlated with population density but seems to be related to the very intense agricultural activity occurring in the local watershed.

\subsection{Effects of damming in coastal fisheries}

Shrimps (Penaeidae), mangrove oyster (Crassostrea rhizophorae) mullets (Mugilidae), mojarras (Gerridae), thread herring (Opisthonema oglinum) and Spanish and king mackerels (Scomberomorus spp.), are some of the most important Cuban marine species commercially, and are representative of the estuarine littoral ecological complex (Baisre, 1985). A negative trend in the landings of several estuarine species over the last 20 years is presented in Fig. 8. It is noteworthy that species such as shrimps, mullets and oyster, presented the more drastic and statistically significantly decreases, while the more mobile species, represented by the pelagic thread herring and Spanish mackerel have not shown any marked decreases.

Analysis of time series of the catches from 1980 to 2003 revealed that the total catches of the three ecological complexes showed a downward trend (Table 1) but that for littoral-estuarine ecological complex showed the most significant decline.

The pelagic to demersal ratio (bony fish only) (De LeivaMoreno et al., 2000) or the piscivore/zooplanktivore ratio (Caddy and Garibaldi, 2000), have been considered sensitive indexes available from fisheries data that reflect the impact of river nutrients on the ecosystem in a formerly oligotrophic environment. In Cuba we chose another index because most the commercial fisheries are based in benthic food chains while

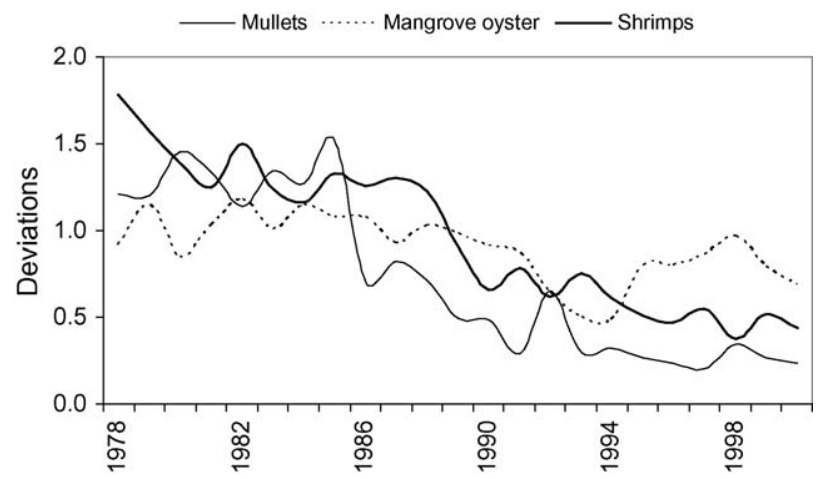

Fig. 8. Trend in the catches of some typical estuarine species, expressed as deviations from the average catch of each species during the whole period of observation. (With permission from Biogeochemistry, Springer.)
Table 1

Parameters of the linear regression of catches against time for the 1980/2003 period

\begin{tabular}{llll}
\hline Fisheries ecological complexes & Intercept & Slope & $R^{2}$ \\
\hline Estuarine-littoral & 61.3 & -0.03 & 0.8574 \\
Seagrasses-coral reef & 33.2 & -0.02 & 0.6909 \\
Oceanic & 47.0 & -0.02 & 0.6627 \\
\hline
\end{tabular}

pelagic fishes, which strictly feed on plankton, are uncommon (Baisre, 1985). In fact, some of the typical pelagic species like thread herring (O. oglinum) feeds on small crustaceans; obtaining a major component of their food from the bottom in estuarine and coastal waters (Vega-Cendejas et al., 1997). Based on this characteristic, we used the ratio between catches of estuarine species to catches of species living in seagrass beds and coral reefs, and this seems to be a more appropriate index if we want to measure the impact of river damming on the fish components of coastal ecological communities. The evolution of this index is presented in Fig. 9. It can be observed that there has been a negative and significant trend in total landings of estuarinedependent species, and that this trend has been more evident since 1990 by which date some of the largest dams were already built, particularly that on the Zaza River, the second largest river of the country.

\subsection{The Cauto River damming and the shrimp fishery: a case study}

The Cauto River system is the largest in Cuba, draining 8.1\% of the total area of the country. The human population density in its watershed is 122 individuals per square $\mathrm{km}$ and forest covers $16 \%$ of the watershed surface. Before damming, this river discharged on average, $1760{\text { million } \mathrm{m}^{3} \text { year }}^{-1}$ of freshwater. The discharge rate varies seasonally, being highest in late spring and summer, and then decreasing through fall to a winter low. Damming of the Cauto River started in 1967 and was complete by 1992 . During this period, 19 dams were built and the flow decreased by $70 \%$ (INRH, 2005).

Shrimps are typical estuarine species and their catches have been commonly correlated with freshwater flows (Garcia and Le Reste, 1981). Due to its large size and annual flow, the Cauto

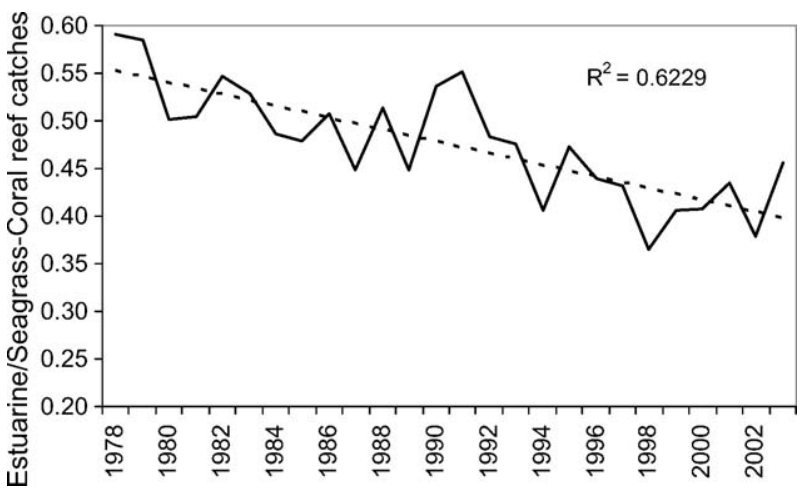

Fig. 9. Index of catches of estuarine species/catches of species associated with seagrasses and coral reefs. 


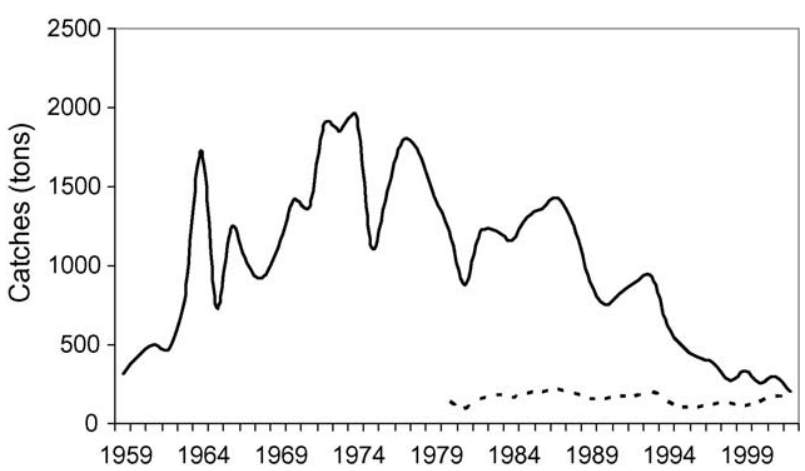

Fig. 10. Evolution of shrimp catches from 1950 to 2002 (solid line) and the corresponding catch per unit of effort (c.p.u.e.) (broken line). The c.p.u.e. is expressed in $\mathrm{kg}$ per fishing day.

River influences a large portion of the Cuban insular shelf along the southeastern coast, and the most important fishing zones for white and pink shrimp and several other estuarine species are in the neighborhood of this river mouth (González, 1984; Baisre, 1985).

Fig. 10 shows the evolution of the shrimp fishery associated with the marine area or catchment influenced by the Cauto River. As discussed by Baisre and Zamora (1983), the high peak catch observed in 1964 provides strong circumstantial evidence for the influence of freshwater flows on shrimp catches. In October 1963, Hurricane Flora provoked very intense rainfall and flooding of the Cauto River, with the water flow increasing more than three-fold with respect to average values (INRH, 2005). This figure also shows a progressive decrease in shrimp catches from 1978 onwards. However, the broken line in the lower part of the figure illustrates that, as a measure of local abundance on the fishing grounds, catch per unit of effort (in $\mathrm{kg}$ per fishing day) has not changed much over the last 20 years in spite of the drastic decrease in catches experienced during the period. This may be interpreted as meaning that fishing effort also decreased as a consequence of the dramatic drop in the abundance and area of distribution of the stock.

As the fishery actually exploits two species of shrimp (the pink shrimp Farfantopenaeus notialis and the white shrimp Litopenaeus schmitti), we also calculated the white shrimp/pink shrimp ratio of the catches in order to assess possible differences related to the ecology of the two species. In Fig. 11, it is clear that

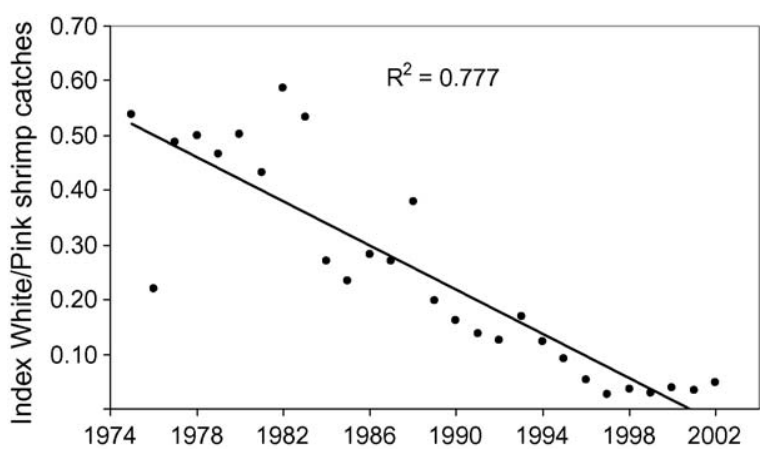

Fig. 11. Index of the ratio of white shrimp to pink shrimp catches. The trend line is also included.

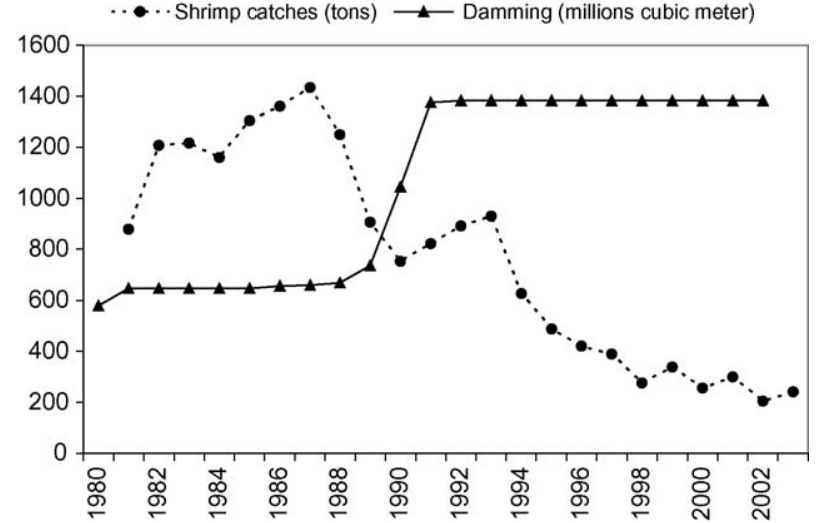

Fig. 12. Relationship between damming of the Cauto River (millions of cubic meters of water) and shrimp catches (in tonnes) in the coastal area receiving drainage from this river.

catches of white shrimp have been more severely affected than those of pink shrimp. It is well known (Kutkuhn, 1966) that some groups of shrimp are more dependent on freshwater (estuarineextreme species) than others (oceanic-extreme species), and in Cuba, white and pink shrimp have different distributions and occupy different nursery areas. The white shrimp has a more restricted distribution in shallower waters and is closer to the coast than pink shrimp which are widely distributed in deeper waters (Baisre, 2004). According to Guitart et al. (1985) the white shrimp spawn close to the mouth of the Cauto River and juveniles are found in coastal lagoons (González et al., 1984) over soft bottom areas associated with mangrove shoots (Páez, 1997). The nursery areas of pink shrimp are in shallow waters, but not in coastal lagoons, with abundant seagrasses (Halodule wrighti and also Syringodium filiforme) (Puga et al., 1982; Páez, 1997). Fig. 12 shows the relationship between shrimp catches in the area influenced by the Cauto River and the damming of that river, showing a significant relationship between the increase of water volume dammed and the decrease in shrimp catches over the period 1972-2003 $\left(R^{2}=0.8144, P<0.001\right)$.

\section{Discussion}

\subsection{Freshwater fisheries}

Different exotic species of tilapia (Cichlids) and Chinese carps (mainly silver carp) have become the dominant freshwater fishes in Cuban reservoirs, replacing native species and dominating the national catch of freshwater fishes. As shown above, species composition in the newly built reservoirs has changed dramatically with a great dominance of silver carp since 1996. Major changes in the fish communities of many lakes of the world have been associated with cultural eutrophication (Hartmann and Nümann, 1977; Persson et al., 1991), and this seems to be also true for Cuban artificial reservoirs. A shift to a fish community dominated by cyprinid fishes in highly productive systems has also been reported in the lakes of Europe and North America, and this numerical dominance has been attributed to a competitive asymmetry (Persson, 1988). Application of the dominance principle is especially relevant to 
culturally disturbed lakes, such as those subjected to eutrophication (Ryder and Kerr, 1984). The dominance of cyprinid fishes in highly productive systems means that eutrophication has negative effects on both water clarity and the economic value of the fish community (Carpenter et al., 1996). The ability of some cyprinids to forage under turbid conditions and their capacity to assimilate blue-green algae both contribute to numerical dominance. Nonetheless, as Carruthers (1986) showed, silver carp may improve water quality by exerting a strong control on phytoplankton biomass (Januszko, 1978; Buck, 1977). Here it is important to highlight that the silver carp, the most important species in Cuban reservoirs, requires standing or slow-flowing conditions such as in impoundments or the backwaters of large rivers. When rearing of silver carp spread in European countries, the main objective was to increase fishery yields from eutrophic waters and to improve water quality in the stocked ecosystems (Barthelmes, 1984). This species feeds on phytoplankton and has been introduced to many countries where its ability to clean reservoirs and other waters of clogging algae is appreciated even more than its food value (Frimodt, 1995). Furthermore, a relatively high fraction of the cells eaten by silver carp may be excreted with appreciable loss of chlorophyll (Miura and Wang, 1985) so that an important part of the plankton production comes from algae which have already passed through fish (Northcote, 1988).

A report typifying the productivity and trophic status of 76 Cuban artificial reservoirs (Quiñones et al., 1990) established three main categories. The reservoirs classified as oligotrophic have less than 1 million cells $1^{-1}$ of phytoplankton and a fisheries yield of less than $100 \mathrm{~kg} \mathrm{ha}^{-1}$ year $^{-1}$; those which are mesotrophic have 1.5-2.5 million cells $1^{-1}$ and a fisheries yield of about $150 \mathrm{~kg}$ ha year ${ }^{-1}$; and the eutrophic reservoirs have more than 3 million cells $1^{-1}$ and a fisheries yield above $200 \mathrm{~kg}_{\text {ha year }}{ }^{-1}$. Eutrophic reservoirs in Cuba represented about $80 \%$ of the whole number studied. The dominance of silver carp, feeding lower in the food chain and taking advantage of the phytoplankton blooms associated with nutrient enrichment in the reservoirs, might explain the high yield observed in many reservoirs.

Marshall and Maes (1994) compared yields from various types of water bodies in the tropics and reported that shallow managed reservoirs averaged $30-150 \mathrm{~kg}$ ha year ${ }^{-1}$ and deep reservoirs averaged $10-50 \mathrm{~kg} \mathrm{ha}^{-1}$ year $^{-1}$. In the review of Jackson and Marmulla (2001) for Latin America and the Caribbean reservoir fishery yields tended to be higher for the Caribbean (Cuba $125 \mathrm{~kg} \mathrm{ha}^{-1}$ year $^{-1}$; Dominican Republic $29-75 \mathrm{~kg} \mathrm{ha}^{-1}$ year $^{-1}$ ) than is generally recorded for Central and South America reservoirs. Higher yields throughout the region typically result from stocking of exotic species and similar patterns exist with regard to fishery yields from reservoirs in temperate zones. The average yield from North American reservoirs is only $24 \mathrm{~kg} \mathrm{ha}^{-1}$ year $^{-1}$. In Europe, records indicate reservoir fishery yields ranging from 21 to $76 \mathrm{~kg} \mathrm{ha}^{-1}$ year ${ }^{-1}$. In the same paper it is also reported that reservoirs yields in China ranged from 127 to $152 \mathrm{~kg} \mathrm{ha}^{-1}$ year $^{-1}$. Excepting China, all of these yields are well below the average obtained from Cuban reservoirs. For Cuba, Juárez-Palacios and Olmos
Tomazini (1992) calculated yield from 15 reservoirs stocked with tilapia over the period 1984-1988. They reported yields ranging from 11.5 to $297.2 \mathrm{~kg} \mathrm{ha}^{-1}$ year $^{-1}$ with an average of $134.7 \mathrm{~kg} \mathrm{ha}^{-1}$ year $^{-1}$. The natural ontogeny of most lakes (and reservoirs) is to become gradually shallower and more productive as they age, and eutrophication greatly accelerates this process (Stockner et al., 2000). This has happened in Cuban reservoirs, and the regression between fisheries yield and anthropogenic activities previously presented is a good indicator that cultural eutrophication processes have taken place in the more productive reservoirs. The nutrient subsides from anthropogenic activities in upland areas might explain why the average fisheries yields in Cuba are considerably higher than those reported for other areas. As pointed out by Jackson and Marmulla (2001), benefits seem more pronounced for smaller, shallower reservoirs that have reasonably high concentrations of dissolved solids and that are located in the upper reaches of their respective river ecosystem.

\subsection{Marine fisheries}

Declines in the catches of commercial exploited marine species have been commonly attributed to changes in fishing effort (Pauly et al., 1998, 2002; Jackson et al., 2001; Pauly, 2003), to cyclic or periodic environmental changes (Finney et al., 2002; Schlesinger and Ramankutty, 1994; Barange et al., 2003) and to cultural eutrophication (Caddy, 2000; Turner et al., 2003). In this paper we have shown that others anthropogenic effects might also provoke a similar drop in the catches of some coastal species. The oligotrophication of the estuarine and coastal waters in Cuba, driven by a drastic reduction in the use of fertilizers and the burning of fossil fuels (Baisre, in press), together with the environmental changes and habitat losses associated to river damming severely depleted the catches of the species which are more dependent on estuaries during their life cycles.

There is strong circumstantial evidence worldwide that nutrient-enriched riverine discharges enhance fishery production on adjacent shelves (e.g., Grimes, 2001). When dealing with terrestrial anthropogenic inputs to the coastal waters, the more important driving functions (Caddy and Bakun, 1995) would be: (1) increased load of nutrients, (2) increased load of sediments and (3) changes in freshwater runoff. When several dams are constructed on upstream tributaries of a river ecosystem, the cumulative effects of these dams can be to block the flow of nutrients from the catchments basin to the lower reaches of the ecosystem, thereby negatively affecting fisheries production in downstream portions of the ecosystems, including estuaries and the adjacent marine environment (Jackson and Marmulla, 2001).

Because the life cycles of estuarine species are wholly or mostly carried out in waters directly influenced by river discharge, critical demographic processes regulating population size such as growth, mortality and recruitment are affected when discharge rates are altered (Grimes, 2001). The reduction in the extent of brackish areas and wetlands by excessive freshwater extraction upstream will have adverse impacts on marine species which are dependent on brackish habitat for part of their life history (Aleem, 1972; Deegan et al., 1986; Caddy and 
Bakun, 1995). A reduction in freshwater flow might concomitantly reduce the extent of the brackish water area, and also provoke salt-water invasion into the estuary and lower river system that will have severe impacts on estuarine-dependent species (Deegan et al., 1986).

The building of dams on rivers increases water retention and the rates of degradation and sedimentation of particulate organic matter and the new impoundment and reservoirs become effective nutrient and sediment sinks (Stockner et al., 2000). The impacts of large dams rapidly and profoundly modify the sediment routing of fine suspended particles to the coastal zone (Meybeck, 2003). In Cuba, the natural evolution of lagoons to swamp and, eventually to drier land, has been accelerated in some areas near to the rivers Zaza (González and Aguilar, 1983) and Cauto (Revilla, 1994), as a possible result of the damming of these rivers, and the consequent substantial decrease in the freshwater supply. All of these effects might reduce the nursery areas and seem to be acting synergistically against recruitment and further development of estuarine species, particularly the white shrimp, because of its great dependence on coastal lagoons and seagrasses (González et al., 1984).

The impact of human activities on nutrient budgets to the coastal zone can be complex owing to a marked increase of inorganic $\mathrm{N}$ and $\mathrm{P}$ due to agriculture and urbanization or a decrease of inorganic $\mathrm{N}$ and $\mathrm{P}$ and of dissolved silica owing to reservoir retention (Meybeck, 2003). All of these changes are reflected in changes in the nutrient ratios (Humborg et al., 1997, 2000) which are responsible for the severe modification of coastal zone food webs (Turner et al., 2003). Cumulative effects of dams on catchments basins and tributary streams are to significantly block nutrient flows through the ecosystem; affecting fisheries production in the downstream estuary and marine environments (Ryder, 1978). For example, reduced fisheries yield in the Black sea and the Sea of Azov are related to impoundments of the Danube, Dnieper and Dniester rivers in Europe (Tolmazin, 1979) suggesting that dams act as nutrient traps. Coastal fisheries depending on upstream inputs can be significantly reduced, as has also been documented in the fisheries of the Nile delta, where the construction of the Aswan dam had impacts on marine fishery production in the Levant (Halim et al., 1995). This example also illustrates the opposing effect to the usual increase in nutrient supply due to human activities, and seems to confirm that both nutrientenhancement and impoverishment processes can impact marine fisheries yields (Caddy, 2000). Anthropogenic nutrient reduction has been termed oligotrophication and impoundment of rivers for hydraulic generation and/or water storage is one of the direct causes of oligotrophication (Stockner et al., 2000).

\subsection{Ecological impacts}

The building of more than 1700 dams on the main river systems of Cuba created a relatively important freshwater fishery based on periodical stocking of these reservoirs. Because of their position with respect to nutrient sources within the catchments basins, some of the largest dams effectively became nutrient sinks, limiting the amount of freshwater and land-based nutrients that otherwise would flow into estuaries and coastal waters.
On the positive side, many of these reservoirs now show relatively high fisheries yields, and as we have shown, there is a significant relationship between fisheries yield and the number of persons in the urban areas upstream of the dams. The interruption of natural fluxes of water, nutrients and sediments by river regulation have had serious ecological impacts downstream from the dams however. Damming the main rivers of the country has accounted for about $30 \%$ of the average annual freshwater flow, and has led to two progressive but inverse processes in Cuba: the eutrophication of artificial reservoirs, and the oligotrophication of estuarine and coastal waters. It is also very probable that oligotrophication in coastal waters has been enhanced by the drastic reduction of primary nutrients inputs from land-based sources, principally from fertilizer application, as reported by Baisre (in press). The reduction of nutrient inputs from agricultural fertilizers to rivers may have acted synergistically with river damming to reduce final nutrient inputs to estuaries and coastal zones.

Although this analysis has been limited to a discussion of the impacts of river damming on coastal fisheries, other ecological consequences of these changes cannot be overlooked. There is growing concern that river damming could leads to severe reductions of dissolved silicate input to the sea and this may have dramatic impacts on aquatic food webs in coastal marine environments (Ittekot et al., 2000). In the lower Mississippi River, nitrate concentrations have more than doubled while the silicate concentration has decreased by $40 \%$; presumably due to biodeposition in reservoirs behind dams (Turner and Rabelais, 1991).

Significant reductions in nutrient inputs to coastal waters may be achieved by approaches that: (1) reduce the use of the fertilizers in the first place; (2) control losses to the environment at the point of release (e.g., from indiscriminate or excessive field fertilization, or supplementary animal feeding operation); (3) sequester or remove pollutants as they are transported to the sea (Carpenter et al., 1996); (4) adopt good riparian practices which ensure that water courses are separated by a buffer zone of natural vegetation from fertilized fields. All of these changes have occurred in Cuba, and must have impacted coastal water and played a role in the decrease of fishery landings experienced since 1990. As pointed out by Caddy (2000), anthropogenic impacts on marine ecosystems might differ from the effects of fishing, but all such effects can be regarded as natural 'stresses' on the original ecosystem and ideally should be evaluated and corrected for.

According to Meybeck (2003), relevant attempts to bridge the gap between system analysis of continental water system and a water resource management analysis have been noted in the evaluation of environmental services given by wetlands, lakes, rivers and groundwaters (Constanza et al., 1997). The strong relationship between the freshwater productivity of a river system and that of its estuary, discussed in this paper, suggest that any economic analysis of watershed productivity should include that of its estuarine area and the zone affected by the marine plume.

\section{Acknowledgments}

We would like to acknowledge Dr. John F. Caddy for the critical review of this paper which considerably improved the 
first draft. We also thank to two anonymous reviewers whose comments improved the manuscript.

\section{References}

Aleem, A.A., 1972. Effect of river outflow management on marine life. Mar. Biol. 15, 200-208.

Arthurton, R., 2005. LOICZ AfriCat 1 -coastal impacts of damming and water abstraction in African catchments. LOICZ Newslett. 34, 1-4.

Baisre, J.A., Zamora, A., 1983. Las Pesquerías Cubanas de Camarón: Antecedentes Situación Actual y Perspectivas. Ministerio Industria Pesquera Publ. Esp, 83 pp.

Baisre, J.A., 1985. Los complejos ecológicos de Pesca: Su importancia en la administración de las pesquerías cubanas. FAO Fish. Rep. 278 (Suppl.), 251-272.

Baisre, J.A., 2004. La Pesca Marítima en Cuba. Editorial Científico Técnica. Instituto del Libro, La Habana, Cuba, 372 pp.

Baisre, J.A. Assessment of nitrogen flows into the Cuban landscape. Biogeochemistry. doi:10.1007/s10533-006-9004-z, in press.

Barange, M., Werner, F., Perry, I., Fogarty, M., 2003. The tangled web: global fishing, global climate, and fish stock fluctuations. Global Change Newslett. $56,24-27$.

Barthelmes, D., 1984. Heavy Silver Carp (Hypophthalmichthys molitrix (Val.) Stocking in Lakes and its Influence on Indigenous Fish Stocks. European Inland Fisheries Advisory Commission, FAO, EIFAC Tech. Pap. 42 Suppl., pp. 313-318.

Buck, D.H., 1977. The integration of aquaculture with agriculture. Fisheries 2 , $11-16$.

Caddy, J.F., Bakun, A., 1994. A tentative classification of coastal marine ecosystems based on dominant processes of nutrient supply. Ocean Coastal Manage. 23, 201-211

Caddy, J.F., Bakun, A., 1995. Marine catchment basins and anthropogenic effects on coastal fishery ecosystems. FAO Fish. Rep. 349, 119-133.

Caddy, J.F., 2000. Marine catchment basin effects versus impact of fisheries on semi-enclosed seas. ICES J. Mar. Sci. 57, 628-640.

Caddy, J.F., Garibaldi, L., 2000. Apparent changes in the trophic composition of world marine harvest: the perspective from the FAO capture database. Ocean Coastal Manage. 43, 615-655.

Carpenter, S., Frost, T., Persson, L., Power, M., Soto, D., 1996. Freshwater ecosystems: linkages of complexity and processes. In: Mooney, H.A., Cushman, J.H., Medina, E., Sala, O.E., Schultze, E.D. (Eds.), Functional Roles Biodiversity: A Global Perspective. SCOPE. John Wiley \& Sons Ltd., pp. 299-325.

Carruthers, A.D., 1986. Effect of silver carp on blue-green algal blooms in Lake Oraki. N. Z. Minist. Agric. Fish. Res. Div. Fish. Env. Rep. 68, 63p.

Chen, C.T.A., 2002. The impact of dam in fisheries: case of the three Georges dam. In: Steffen, W., Jarger, J., Carson, D.J., Bradshaw, C. (Eds.), Challenging of a Changing Earth. Springer, Berlin, pp. 97-99.

Constanza, R., d'Arge, R., de Groot, R., Farber, S., Grasso, M., Hannon, B., Limburg, K., Naeem, S., O’Neill, R.V., Robert, V., Paruelo, J., Raskin, R.G., Sutton, P., van den Belt, M., 1997. The value of the world's ecosystem services and natural capital. Nature 387, 253-260.

Deegan, L.A., Day Jr., J.W., Yañez-Arencibia, A., Gosselink, J.G., SoberónChávez, G., Sánchez-Gil, P., 1986. Relationships among physical characteristics, vegetation, distributions, and fisheries yield in Gulf of Mexico estuaries. In: Wolfe, D.A. (Ed.), Estuarine Variability. Academic Press, New York, pp. 83-100.

De Leiva-Moreno, J.I., Agostini, V.N., Caddy, J.F., Carocci, F., 2000. Is the pelagic-demersal ratio from fishery landings a useful proxy for nutrient availability? A preliminary data exploration for the semi-enclosed seas around Europe. ICES J. Mar. Sci. 57, 1091-1102.

Downing, J.A., Mcclain, M., Twilley, R., Melack, J.M., Elser, J., Rabalais, N.N., Lewis Jr., W.M., Turner, R.E., Corredor, J., Soto, D., Yañes-Arencibia, A., Kopaska, J.A., Howarth, R.W., 1999. The impact of accelerating land-use change on the $\mathrm{N}$-cycle of tropical aquatic ecosystems: current conditions and projected changes. Biogeochemistry 46, 109-148.
FAOSTAT, 2005. FAO Statistical Database. Last updated on February 2005. http://faostat.fao.org/faostat/collections?subset=fisheries

FAO/AQUASTAT, 2000. FAO's Information System on Water and Aquaculture. http://www.fao.org/ag/agl/aglw/aquastat/countries/index.stm.

Finney, B.P., Gregory-Eaves, I., Douglas, M.S.V., Smol, J.P., 2002. Fisheries productivity in the north-eastern Pacific Ocean over the past 2200 years. Nature 416, 729-733.

Frimodt, C., 1995. Multilingual Illustrated Guide to the World's Commercial Coldwater Fish. Fishing News Books. Osney Meand, Oxford, England, 215 pp.

Garcia, S., Le Reste, L., 1981. Life Cycles, Dynamics, Exploitation and Management of Coastal Penaeid Shrimp Stocks. FAO Fish. Tech. Pap. 203, 215 pp.

González, C., Guitart, B., González, E., Fraga, I., Reyes, R., 1984. Distribución y abundancia de preadultos de camarón blanco (Penaeus schmitti) en dos lagunas de Tunas de Zaza, Cuba. Rev. Cub. Inv. Pesq. 9 (1-2), 21-41.

González, G., 1984. Ecología de las lagunas costeras de la región suroriental de Cuba. Rev. Inv. Mar. 5 (1), 127-171.

González, G., Aguilar, C., 1983. Estudio comparativo de la estructura de las comunidades de peces de las lagunas costeras de la región sur-oriental de Cuba. Rev. Inv. Mar. 4 (2), 91-124.

Grimes, C.B., 2001. Fishery production and the Mississippi River discharge. Fisheries 26 (8), 17-26.

Guitart, B., González, E., Fraga, I., Reyes, R., 1985. Áreas y épocas de desove de los camarones Penaeus notialis y P. schmitti en la plataforma cubana. Rev. Cub. Inv. Pesq. 10 (3-4), 57-76.

Halim, Y., Morcos, S.A., Rizkalla, S., El-Sayed, M.K., 1995. The Impact of the Nile and the Suez Canal on the Living Marine Resources of the Egyptian Mediterranean Waters (1958-1986). FAO Fish. Tech. Pap. 349, pp. 1950.

Hartmann, J., Nümann, W., 1977. Percids of Lake Constance, a lake undergoing eutrophication. J. Fish. Res. Bd. Can. 34, 1670-1677.

Howarth, R.W., Anderson, D., Cloern, J., Elfring, C., Hopkinson, C., Lapointe, V., Malone, T., Marcus, N., McGlathery, K., Sharpley, A., Walker, D., 2000. Nutrient pollution of coastal rivers bays and seas. Issues Ecol. 7, 15.

Humborg, C., Ittekot, V., Cociasu, A., von Bodungen, B.V., 1997. Effect of the Danube River dam on Black Sea biogeochemistry and ecosystem structure. Nature 386, 385-387.

Humborg, C., Conley, D.J., Rahm, L., Wolff, F., Cociasu, A., Ittekot, V., 2000. Silicon retention in river basins: far reaching effects on biogeochemistry and aquatic food webs in coastal marine environments. Ambio 29, 49-50.

INRH, 2005. Cuban Database on Water Resources. http://www.hidro.cu/.

Ittekot, V., Humborg, C., Schäfer, P., 2000. Hydrological alterations and marine biogeochemistry: a silicate issue? Bioscience 50 (9), 776-782.

Jackson, D.C., Marmulla, G., 2001. The Influence of Dams in River Fisheries. FAO Fish. Tech. Pap. 419, pp. 45-90.

Jackson, J.B.C., Kirby, M.X., Berger, W.H., Bjorndal, K.A., Botsford, L.W., Bourque, B.J., Bradbury, R.H., Cooke, R., Erlandson, J., Estes, J.A., Hughes, T.P., Kidwell, S., Lange, C.B.X., Lenihan, H., Pandolfi, J.M., Peterson, C.H., Steneck, R.S., Tegner, M.J., Warner, R.R., 2001. Historical overfishing and the recent collapse of coastal ecosystems. Science 293, 629-638.

Januszko, M., 1978. The influence of silver carp (Hypophthalmichthys molitrix Val.) on eutrophication of the environment carp ponds. Part III. Phytoplankton. Rocz. Nauk. Roln. Ser. H. Rybactwo 99 (2), 55-79.

Juárez-Palacios, J.R., Olmos Tomazini, M.E., 1992. Tilapia in capture and culture enhanced fisheries in Latin America. FAO Fish. Rep. 458 (Suppl.), 244-273.

Kutkuhn, J.H., 1966. The role of estuaries in the development and perpetuation of shrimp resources. Sp. Publ. Am. Fish. Soc. 3, 16-36.

LOICZ, 2005. Land Ocean Interactions in Coastal Zone. Biogeochemical Modelling Node. http://data.ecology.su.se/rivel.xls

Marshall, B., Maes, M., 1994. Small Water Bodies and their fisheries in Southern Africa. CIFA Tech. Pap. 29. FAO, Rome, 68 pp.

Meybeck, M., 2003. Global analysis or river systems: from earth system controls to Anthropocene syndromes. Philos. Trans. R. Soc. Lond. B 358, 1935-1955.

Miura, T., Wang, J., 1985. Chlorophyll a found in feces of phytoplanktivorous cyprinids and its photosynthetic activity. Verh. Int. Ver. Limnol. 22, 2636-2642. 
Northcote, T.G., 1988. Fish in the structure and function of freshwater ecosystems: a "top-down" view. Can. J. Fish. Aquat. Sci. 45, 361-379.

ONE (Oficina Nacional de Estadísticas), 2005. Anuario Estadístico de Cuba 2004. Oficina Nacional de Estadísticas, p. 371.

Páez, J., 1997. Las pesquerías de camarón en la plataforma cubana. FAO Fish. Rep. 544 (Suppl.), 155-179.

Pauly, D., Christensen, V., Dalsgaard, J., Froese, R., Torres Jr., F., 1998. Fishing down the food webs. Science 279, 860-863.

Pauly, D., Christensen, V., Guénette, S., Pitcher, T.J., Rashid Sumaila, U., Walters, C.J., Watson, R., Zeller, D., 2002. Toward sustainability in world fisheries. Nature 418, 689-695.

Pauly, D., 2003. Ecosystem impacts of the world's marine fisheries. Global Change Newslett. 55, 21-23.

Persson, L., 1988. Asymmetries in competitive and predatory interactions in fish populations. In: Ebenman, B., Persson, L. (Eds.), SizeStructured Populations-Ecology and Evolution. Springer, Berlin, pp. 203218

Persson, L., Diehl, S., Johansson, L., Anderson, G., Hamrin, S.F., 1991. Shifts in fish communities along the productivity gradient of temperate lakes: patterns and the importance of size-structured interactions. J. Fish Biol. 38, 281-293.

Puga, R., Pérez, A., Alfonso, S., 1982. Características de la etapa juvenil de Penaeus notialis y $P$. schmitti en relación a su ciclo vital en la Ensenada de la Broa. Rev. Cub. Inv. Pesq. 7 (4), 1-25.

Quiñones, N., Martínez, R., Rodríguez, L., Romero, C., 1990. Trophic classification of Cuban reservoirs. In: Quesada, V., Gutiérrez, J., Landner, L. (Eds.), Water Resources Management and Protection in Tropical Climates. Selected
Papers from the First International Symposium. Havana, Cuba, pp. 234 241.

Revilla, N., 1994. Inventario del sistema lagunar del Cauto utilizando sensores remotos. Rev. Cub. Inv. Pesq. 18 (3), 56-59.

Ryder, R.A., 1978. Fish yield assessment of large lakes and reservoirs-a prelude to management. In: Gerking, S.A. (Ed.), Ecology of Freshwater Fish Production. Blackwell Scientific Publications, London, United Kingdom, pp. 403-423.

Ryder, R.A., Kerr, S.R., 1984. Reducing the Risk of Fish Introductions: A Rational Approach to the Management of Integrated Coldwater Communities. European Inland Fisheries Advisory Commission, FAO, EIFAC Tech. Pap. 42 Suppl., pp. 510-533.

Schlesinger, M.E., Ramankutty, N., 1994. An oscillation in the global climate system of period 65-70 years. Nature 367, 723-726.

Stockner, J.G., Rydin, E., Hyenstrand, P., 2000. Cultural oligotrophication: causes and consequences for fisheries resources. Fisheries 25 (5), 7-14.

Tolmazin, D., 1979. Black Sea—dead sea? New Scientist 84 (1184), 767-769.

Turner, R.E., Rabelais, N.N., 1991. Changes in Mississippi water quality this century: implications for coastal food webs. Bioscience 41, 140-147.

Turner, R.E., Rabelais, N.N., Justic, D., Dortch, Q., 2003. Global patterns of dissolved N, P and Si in large rivers. Biogeochemistry 64, 299-317.

Vega-Cendejas, M.E., Mexicano-Cíntora, G., Arce, A.M., 1997. Biology of the thread herring Opisthonema oglinum (Pisces: Clupeidae) from a beach seine fishery of the Campeche Bank, Mexico. Fish. Res. 30, 117-126.

Vörosmarty, C.J., Sharma, K.P., Fekete, B.M., Copeland, A.H., Holden, J., Marble, J., 1997. 